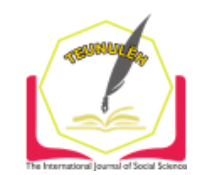

Jurnal Ilmiah Teunuleh

The International Journal of Social Sciences

Vol. 1, Issue. 2, Dec 2020

E-ISSN: 2746-4393

\title{
ORIENTALISTS AND THEIR STUDY OF THE QUR'AN
}

\author{
Nazar Fadli ${ }^{1}$ \\ Muhammad Faisal ${ }^{2}$ \\ Triansyah Fisa ${ }^{3}$ \\ ${ }^{1}$ Necmettin Erbakan Üniversitl, Turkey \\ ${ }^{2}{ }^{3}$ STAIN Teungku Dirundeng Meulaboh \\ 1n.fadli@gmail.com, 2mfaisal705@yahoo.com, ${ }^{3}$ fisa@outlook.co.id
}

\begin{abstract}
The study of orientalists and their thoughts on the eastern world became one of the important studies for Muslim scholars. Especially his thoughts concerning the most substantial things in the eastern world. The eastern world that is synonymous with Islam is very interesting to be studied by Western Scholars. The Qur'an which became the main source of life for Muslims became the most important object studied by orientalists. Generally orientalists opinions of the Qur'an give birth to negative opinions that tend to criticize the authenticity of the Qur'an. Orientalists approache in the study of the Qur'an can be grouped into three parts. The first, Historically-critical, that is, reviewing a narrative by looking at what really happened. These criticisms include forms, editors, and sources. The second. Interpretive interpretation, i.e. interpreting the text using one of three methods; philology, literature, and lingustics. The third, phenomenologists, namely describing the reception of the Qur'an carried out by individuals of a particular group. According to Syamsuddin Arif, there are many ways or techniques used by orientalists to question their authenticity, where the classic issue that is often raised is the influence of Jews, Christians, Zoorosters, and so on on Islam and cages in the Qur'an (Theories of borrowing and influence). Some of them are trying to reveal what could be evidence for the loan theory and its influence. Especially from Jewish-Christian literature and traditions (such as Abraham Geiger, Clair Tisdall, and others). There are also those who compare the teachings of the Qur'an with the customs of Jahiliyyah, Roman and so on.
\end{abstract}

Keywords: Orientalists, View, Qur'an. 


\section{A. Introduction}

The study of Islamic studies from the western world of the eastern world popularly known as orientalism is a long-lasting activity. It is believed that orientalism began in the $11^{\text {th }}$ century $A D$ when many Europeans went to school and studied in Arab colleges with the orientation of mastery and translation of Arabic textbooks. (Said, 1996)

Orientalist activities or eastern studies itself experience travel and winding dynamics. Similarly, the motivation of orientalists in studying Islam undergoes a changing dynamic according to the developing situation. Before the $19^{\text {th }}$ century, for example, orientalist motivations were not far from the motivations of colonialism and the spirit of hostility towards Islam. The view presented is dominated by polemis attitude. But since the 19th century that motivation has begun to shift. Orientalism is no longer solely aimed at finding weaknesses in Islamic teachings, but has begun to be motivated by scientific goals. (Goldziher, 1971)

Among the orientalist figures considered the most prominent of his works and thoughts in the study of the Qur'an and hadith was Ignaz Goldziher, who in his travels inspired many other orientalists such as Joseph Schacht and G. H. A. Juynboll. (Nurhaedi, 2003)

This paper will briefly discuss the views of Islamic outsiders such as Goldziher, Hendreak Kreamer, George Sale, Richard Bell et al against the authenticity of the Qur'an, the author realizes this paper is far from perfection therefore the author expects criticism and advice from readers for the improvement of this paper.

\section{B. FINDING AND DISCUSSION}

1. Orientalist Understanding

Before entering because of the study of orientalists in depth, it is good to know about the understanding of orientalists themselves. Orientalis according to language comes from the word orient which means east (Hanafi, 1981). Geographically, this word can be interpreted as "eastern world" and 
ethnologically means nations in the east (Shihab, 1999). Based on this understanding, orientalists is a study that is based on a study of the objects of the eastern world conducted by other than easterners on various eastern disciplines, both in the field of language, religion, history, anthropology and socio-cultural problems of eastern nations with a Eurocentris approach. (Yurnalis, 2019).

According to Prof. Ismail Jakub. Orientalists come from the word oriental and ism. Oriental means Eastern, and Ism means a word that points to an understanding, teachings, ideals, ways, systems and attitudes. Therefore orientalism can be interpreted with eastern teachings and understandings. It's about eastern matter. (Agustiar, 2015).

\section{Brief History of Orientalist Development}

The emergence of orientalists is the study of Western scientists on the eastern world in the form of literature, history, customs, politics, environment, and religion in East Asia Including Islam. The rise of the spirit of Western scientists who learn about the eastern world has actually arisen from ancient times, even since medieval times. Their interest has spawned a number of works. At least in general. It can be divided into three periods, namely (1) the period before the outbreak of the crusades at a time when Muslims were in their golden age (6501250), (2) the period of crusade until the time of enlightenment in Europe, and (3) The emergence of enlightenment in Europe until now (Rahim, 2010). Orientalist studies generally examine all aspects of life in the eastern world. But among those aspects. The Qur'an is one of the most important studies for orientalists considering the eastern world that is closely related to the Muslims and the Qur'an becomes the main source for Muslims. Many orientalists concentrated their study of the Qur'an.

Syamsuddin Arif in his book Orientalis and Diabolism of Thought explains in 1927, Alphonse Mingama, an Iraqi Christian pastor and former professor at the University of Birmingham, England announced that "the time has come to conduct a critical study of the Qur'an as has been done against the Hebrew- 
Arami-speaking Jewish scriptures. Surely Mingama is not the first to make such a call, nor is he alone (Arif, 2008).

Long before mingama, in 1834 in Leipiz (Germany), an Orientalist named Gustav Flugel published the "mushaf" of philological studies. The manuscript he made was called Corani Textus Arabicus. Next came Theoder Noldeke who wanted to reconstruct the history of the Qur'an in his work Geschichte des Qorans (1860), then in 1937. Arthur Jeffery's ambition was to create a critical edition of Aqur'an, transform the existing Ottoman Mushaf and replace it with a new mushaf. Conon Arthur Jeffery also wanted to restore the text of the Qur'an based on the book of al-Mashahif by Ibn Abi Dawud as-Sijistani who is thought to record the readings in several 'mushaf counterpoints. Jeffery intends to continue the efforts of Gotthelf Bergstrasser and Otto Pretzl, two German orientalists who have also done their best to collect manuscripts of the Qur'an with the aim of creating a critical edition of the Qur'an. The project ultimately failed because all of its archives in Munich were destroyed by bombs during the Second World War (Arif, 2008).

The picture above has at least shown orientalist studies of the eastern world, especially the study of the Qur'an seems to want to see the weaknesses of the Qur'an even some who want to question the authenticity of the Qur'an. Many ways or techniques are used by orientalists to question its authenticity, where the classic issue that is often raised is the influence of Jews, Christians, Zoorosters, and so on on Islam and cages in the Qur'an (Theories of borrowing and influence). Some of them are trying to reveal what could be evidence for the loan theory and its influence. Especially from Jewish-Christian literature and traditions (such as Abraham Geiger, Clair Tisdall, and others).

There are also those who compare the teachings of the Qur'an with the customs of Jahiliyyah, Roman and so on. Generally they say that the stories told in the Qur'an are many erroneous and do not correspond to the Bible version which they consider accurate. But whatever way they do it is like a froth in the sea that comes and disappears instantly that without succeeding in changing the beliefs and respect of Muslims towards the Holy Book of the Qur'an (Arif, 2008). 
At least in his study of the Qur'an, orientalists used three approaches. First, a historically-critical approach, a study of a narrative by looking at what really happened. This criticism is done to the form, editors, and sources. Second, interpretive approach to interpreting the text using one of three methods; philology, literature, and linguistics. Third. Phenomenological, which describes the reception of the Qur'an performed by individuals of a particular group (Hasbiyallah, 2018).

\section{Some Orientalists who study the Qur'an}

1. Ignaz Goldziher's views on the Qur'an

As a holy book of Allah revealed to the Prophet Muhammad (verbum dei), the Qur'an has been believed by Muslims for generations as an authentic and original holy book. The originality and authenticity is not only related to the process of revelation but also related to its meaning and content (Qath'iy aldalalah and qhatiy al wurud). However, what is the authenticity and originality of the Qur'an in the eyes of orientalists?

In relation to the study of the Qur'an and its interpretation, Goldziher can be said to be an orientalist figure whose opinions are widely referred to by orientalists afterwards. His opinions and views on the Qur'an can at least be traced through his two works, Introduction to Islamic Theology and Law and Madzahib al-Tafsir Al-Islamiy.

In his work Madzahib al-Tafsir Al-Islamiy, Goldziher himself, in addition to being sued for his views that are considered polemis and skeptical of the Qur'an, he is considered as an orientalist figure who merits in mapping the thoughts of the mufassir especially from the ideological aspects or interpretation activities carried out. In his work, Goldziher purposively managed to select the mufassir from various schools in a nutshell. He assumes the existence of five interpretation schools in Islam: Traditionalist, dogmatic, mystical, sectarian and modernist. The first three schools are in line with the typology of Muslim scholarship, namely the interpretation of bi---riwayah; interpretation of bi-I-dirayah; interpretation of bi- 
I-isyarah. While the other two schools, sectarian and modernist, are additional categories or elaborations of the typology of Muslim scholarship. (Amal, 2001)

The birth of Goldziher's work then triggered the birth of other works that discussed the sect or aliaran tafsir based on many points of view, for example alTafsir wa Al-Mufassirun by Muhamad Husein al-Dzahabi (1961).

Furthermore, when talking about the Qur'an, According to Goldziher is a holy book that seeks to absorb the teachings of the previous samawi religion. The Christian elements in the Qur'an were accepted by Muhammad generally through the path of apocryphal traditions and through heresy-heresy scattered within the Eastern Church. In this way not a few genostic elements of the East get their place in the holy preaching of Muhammad. These ideas in Goldziher's view were obtained by Muhammad through outward relationships in trade when he was still not appointed as an Apostle. To reinforce his argument, Goldziher stated that the doctrines and institutions of the Prophet were eclectic.

Jews and Christians provide the same basic elements and measure. Five basic elements known as the Pillars of Islam have been introduced by the Prophet in the Makkah period obtained a definite form in the period of Medina. Thus, according to Goldziher, the teaching elements in the Qur'an actually absorbed many elements or traditions of the previous religion. For example, first, prayer for example, according to Goldziher, which begins from standing, takbir and readings have similarities with eastern Christian traditions such as prostration, kneeling, and ablution. Second, zakat institutions that are all voluntary charities, by Muhammad then institutionalized formally in the form of donations paid in particular to the community dhu'afa group. Third, fasting which was originally performed on the tenth day of the first month (on the First Day of Redemption in The Jews, Ashura'), then performed during Ramadan, the tenth month according to the lunar calendar; fourth, the pilgrimage to the Ka'ba, the Temple, the ancient Arab holy site in Mecca was reinterpreted in monotheist style from the perspective of Ibrahim's teachings. (Goldziher, 1971, p. 12).

Goldziher also assessed that the Qur'an that was revealed at the time of Rasullullah life was not able to answer various problems that occurred after the 
Prophet died, this is because the coverage of the Holy Qur'an is still only around the basics of the law. Coupled with the widespread expansion of Muslims, this indicates that the presence of Islam has not been able to answer all the problems that exist because new improvements exist after the results of the next generation ijtihad obtained. (Goldziher, 1991)

Goldziher's view above seems to be strongly influenced by the historicalsociological approach that he did in studying Islam, so that a ritual and religious teachings are always seen historically, so that there are similarities in the teachings of Islamic rituals with rituals of religions other than Islam recorded in the Qur'an is considered an effort of plagiarization and absorbance terhdapa teachings before.

Furthermore, related to the Qur'an, Goldziher also has a view that is no less controversial and invites debate. According to him, there is no book of legislation (tasyri') recognized by religious groups - with theological recognition-that it is a text revealed or revealed, in which the early days of its transmition came in a chaotic and uncertain form as the Qur'an found (Goldziher, 2006). The uncertainty referred to by Ignaz Goldziher is the religious version of the reading (qiraa't). According to him, the difference in the variety of readings in reciting the Qur'an (qiraa'at) is caused by the absence of a period in the Qur'an, so that each reader has the authority to determine the reading according to his wishes.

In reinforcing his assumption, Goldziher presents several potential examples that he divides into two groups: (Goldziher, 2006)

a. The difference in reading is because there is no dot. According to Goldziher, the birth of most of the different versions of the reading is returned to the karekteristic Arabic writing itself whose written letter form can present different reading vowels, depending on the difference in the period placed on the form of letters or below and how many points, for example:

$$
\text { وهو الذي يرسل الرياح بشرا can be read وهو can be read وما كنتم تستكبرون يرسل الرياح نشرا }
$$

b. Differences due to the absence of diacritical marks or punctuation in the form of harakat or syakal trigger differences in the position of i'rab (position of the 
word) in a sentence that causes the birth of differences in meaning. Thus, Goldziher came to the assumption that the difference due to the absence of dots (letter marks) and harakat differences produced, put together and formed from silent letters (not read) is the main factor in the birth of reading differences in texts that have no point at all or whose point is not clear. (Goldziher, 2006)

Goldziher's opinion above, got a rebuttal from Muslim scholars, including Muhammad Mustafa Al-A'zami, an expert on the Qur'an and hadith born in India. According to Al-Azami, Goldziher's opinion that the birth of the reading variant is due to the absence of dots and diacritical is incorrect, because the various qiraaters in the Qur'an are not caused by non-sign texts, but have been determined through a famous narration spoken by the Prophet himself and conveyed to friends. Furthermore, A'zami also stated that Goldziher had forgotten the tradition of oral or oral teaching which became the tradition of qur'anic narration. In this context, the mushaf Usmani is a tool to select the entry of qira'at-qiraat ghairu masyhurah or syadz. So Mushaf Usmani itself is not a form of hegemony or uapaya usman to standardize the Qur'an in a version of the reading, as alleged by Goldziher (al-A'zzami, 2005). Here are some orientalist views of the Qur'an:

a. The Qur'an is not the Kalam of Allah

An orientalist named Hendreck Kreamer expressed his view of the Qur'an in his book entitled Islam as follows:

"The Book of the Qur'an comes from three parties. First, a kind of mind and the acquisition of the Prophet Muhammad himself arising by the association of the Prophet with others. From that comes the khutbah about Allah ta'ala the One, the Day of Resurrection, punishment, and the shari'a religion. Secondly, the Prophet got it from the Jews and A.D. at that time. For example, about fasting, zakat, prayer, the stories of the Prophet and others. Third, the various forms that arise in his memory or that he hears are then introduced as the word of God". (Athaillah, 2007)

According to him also, some of the contents of the Qur'an are obtained from the Old Testament, while the teachings on the Day of Resurrection which are basically unknown to the Arabs come from the religion of Ad. Kreamer argued 
this after he saw some similarities between some of the contents of the Qur'an and the Old and New Testament books. (Athaillah, 2007)

Besides Hendreck Kreamer, another orientalist who agrees with him is George Sale. In the opening of an English translation of the Qur'an published in London in 1736, he wrote:

"Muhammad is the author of the Qur'an and its main originator, this is undisputed. Although Muhammad's cooperation with others to write it was achieved, it is necessary to believe that such cooperation is not an easy thing, because his followers never denied it." (Jamal, 1991)

George Sale was an orientalist who pursued Islam to the stage as if he were an actual Muslim. George Sale's argument in 1841 was re-opened to a French translation of the Qur'an by another orientalist named Kasmirski. The opening has been a scientific and flagship reference for orientalists for a long time. They say it encompasses the teachings of Islam in its entirety.

Ricard bell, author of the book "Introduction to The Qur'an" argues that when the Prophet Muhammad wrote the Qur'an clinging to the scriptures, especially to matters related to the past (in the stories section). Some of the stories of the torment (e.g. 'Ad and Thamud) are arabic, but the majority of what Muhammad used to interpret and support his teachings was from Jews and Christians. His chance to stay in Medina was used to get to know ancient times, because it was in Medina that he became acquainted with generations of Jews. We bestowed We gave Moses the Book, and made it a guide for the Children of Moses.

John Pitt, an Exeter-born orientalist in his book "A True and faithful Account of Religion and Manner of Muhammadens" says that the Qur'an is not a revelation of God, further saying that the Qur'an is an unnecessary book because the Qur'an is a collection of fairy tales and false legends full of contradictions and confusion between verses one verse to another. Therefore John Pitt strongly opposed if the Qur'an was likened and aligned with other scriptures.

In medieval times, a number of Orientalists in Europe examined the concepts of Muhammad and they agreed to say that the Prophet Muhammad 
was not a Prophet who received revelation from God. Therefore, Gustav Weil dared to take a smudding by saying that the Prophet Muhammad was a sufferer of epilepsy (ayan). Aloys Spreanger added Gustav Weil's opinion by saying that the Prophet Muhammad was experiencing severe hysteria. Even in claiming the validity of the Prophet Muhammad as the recipient of revelation, another orientalist named Thomas Patrick Huges said in his book The Dictionary of Islam that the Prophet Muhammad pretended not to be good at writing and reading so that the Qur'an could be used as a miracle that proves that Muhammad is an Apostle of God. (Jamal, 1991)

This view is a negative orientalist view of the Qur'an. Frithjof Schoun, an objective orientalist, said that the Qur'an is an important book to study as part of science. He said that the texts of the Qur'an contain spritual meanings that are covered and summarized in the beauty of the Qur'anic language. The Qur'an is not a legend of falsehood, nor is it just a kalam of God, a collection of sounds, languages, and letters, but also a wonderful excellence and perfection of language. The Qur'an is a perfect poem and very high in value. However, the Qur'an is not a verse. (Zuhdi, 2004)

There is no denying the main reason orientalists allege that the Qur'an is made by the Prophet Muhammad because of a grudge against Islam. And those who disbelieve say, "We believe in the Lord of Moses and The Christian, and we have been sent with you with the Truth, and we have prepared for the disbelievers a book. Even the Qur'an firmly rejects the concept of the Trinity of Christianity. (Zuhdi, 2004)

b. Orientalist Criticism of the Compilation of the Qur'an

The next gate used by orientalists as an attacking tool against the Text of the Qur'an, one of which is blasphemous about the writing and compilation. Orientalists questioned why if the Qur'an had been written since the time of the Prophet Muhammad, 'Umar was worried about the death of the huffazs at the battle of Yamamah and told Abu Bakr of the possible disappearance of this Scripture because of their deaths. Furthermore, why are the materials that have 
been written not stored under the care of the Prophet Muhammad himself? If so, why can't Zaid bin Thabit take advantage of the Suhuf setting up? Although the news was narrated by al-Bukhari and considered valid by all Muslims, the explanation was nevertheless considered by orientalists that what was dictated from the beginning and its writing was considered false.

According to Athur Jeffery, Western scientists do not agree that the composition of the Qur'anic texts that are in our hands today, is the same as what existed in the time of the Prophet Muhammad. Here what Jeffery means is the order of his surahs and verses.

Say there is a manuscript of the Qur'an belonging to the Prophet Muhammad. why did he neglect to leave it to the Companions to be listened to and utilized? It is likely that, out of concern, any nasikh-mansukh, the emergence of new revelations, or the transfer of the sequence of verses will not be reflected in the manuscript in the future. In this case, he will make misinformation and do something that harms his people; the losses are felt to be greater than the benefits. If the text existed, why did Zaid ibn Thabit not use it as a major source in the reign of Abu Bakr? Previously, I have stated that in order to obtain the legitimacy of a document, a student must act as an eyewitness and receive directly from his/her personal teacher. If the element of testimony never materializes, the existence of the book of a scientist who has passed away, for example, will cause a loss of value of that text. This is what Zaid ibn Tsabit did in dictating the verses of the Qur'an to the Companions. The Prophet Muhammad instituted a more trusted network of history pathways based on the relationship between teachers and students; on the contrary, since he never submitted written materials, there is no element of testimony that occurs in leather paper manuscripts that can be used as the main source for comparative purposes, both by Zaid and others.

But if the entire Qur'an has been recorded through writings during the life of the Prophet Muhammad and kept in both his supervision and the Companions, why is umar afraid of losing the Qur'an because of the martyrdom of the huffaz? This is again, concerning the law of testimony. 
With the number of thousands, the huffaz gained the knowledge of the Qur'an through the only successive authority on the earth that finally reached the Prophet Muhammad After he died, they (the companions) became a source of authority that also successively. They almost threatened to cut off the testimony that ended in the Prophet Muhammad which resulted in the knowledge that was given less authority.

Likewise, if they record their verses using handwriting, they lose value altogether, because the owner has entered the burrow and cannot confirm the truth. Although there may be a glimmer of written material that is inadvertently exactly the same as the Qur'an as memorized by others, as long as there is still a suitable primary witness, it will be the highest, ranking third in the valid documents. That is why in compiling Suhuf, Abu Bakr persisted in his stance that everyone must not only bring a verse, but also two witnesses to prove that the delivery of the reading came directly from the Prophet Muhammmad (we find this law of testimony was also revived in the reign of 'Uthman).

The verses that have been written are preserved in the shelves and storage cabinets, whether the land of Yamamah sucks the blood of the huffaz or not, but the authority of the witness that is the most important point dalarn determine the integrity of the value of a document, which is most used as the central point of concern 'Umar.

\section{c. Changing the Qur'an}

In 1847, Gustav Flugel printed a type of Qur'anic index. He also drained the energy of wanting to change the Arabic-language texts of the Qur'an and ultimately produce a work that is unacceptable to readers of the Qur'an. It has become an agreement among Muslims, to read the Qur'an must be according to the reading style of one of the seven famous reading experts who all follow the framework of the writing 'Uthmani and sunnah in its reading (qira'ah), the differences that exist, mostly revolve around some diacritical reading marks that have no effect at all on the content of the verses. Each Mushaf printed rests on one of the Seven Qira'at followed uniformly from start to finish. But Flugel used 
all seven reading systems and chose one qira'ah here and there erratically (for no good reason) that only resulted in a worthless cocktail concoction. Even Jeffery (who is known to be not very friendly with Islamic tradition) is cynical by saying:

"The Flugel edition, whose use is so widespread and repeatedly printed, is i.t.a. a text that is very relapsed, because it does not represent the tradition of pure eastern text or text from the various sources it prints, and has no responsible scientific basis." (Armas, 2003)

\section{d. Perversion of the Meaning of the Qur'an}

Robert of Keton, published the Western-produced Qur'an with a translation system of "publishing censorship". Christian defenders hold on to the Westernproduced Qur'an and other muddled translations and they interpret it according to their desires. Peter The Venerable, Pedro Paskal, and Ricardo understood the Qur'an in their own way, which is to prioritize their own interpretations of the Qur'an compiled by Muslims. In fact, they rejected the interpretation of the Qur'an by Muslims as daniel said.

Orientalists study the Qur'an with various translations to distort it intentionally or because of ignorance and do not aim to understand the Qur'an as a divine book. Their purpose is to distort the truth and look for a backrest or means of gospel study. The Qur'an commands that Muslims should believe in Jesus and the revelations sent down to him. So they assumed that the gospel they held was divine. They rejoice in what the Qur'an has given them, but they do not believe in it. (Assamurai, 1996)

e. The Qur'an comes from the Jews

Contemporary orientalists such as Andrew Rippin also recognized that Abraham Geiger first adopted a new approach, namely by using modern aspirations in understanding the Qur'an. Geiger wrote his work in Latin, then published in 1833 in German as Was Hat Muhammed aus dem Judenthum aufgenommen? (What did Muhammed Borrow from Judaism?. It was written to participate in the competition to enter the University of Bonn in 1832. 
In his work Geiger holds that the words contained in the Qur'an such as ark, torah, Jannatu'Adn, Jahannam, Ahbar, Darasa, Rabani, Sabt, Taghut, Furqan, Ma'un, Masani, and Malakut are derived from Hebrew. In addition to the above words Geiger then argued that the Qur'an is also influenced by the Jewish religion when presenting the following. First, matters concerning faith and doctrine. Second, the rule of law and morals, and the third view of life. (Armas, 2003)

\section{CONCLUSION}

From the above exposure can be concluded that the view of outsiders of Islam to the Qur'an is far contrary to the view of Islam itself because orientalists from western scholars master the teachings of Islam and the Qur'an is not to believe it, but only to look for the weakness of the Qur'an with the aim that Muslims shift their viewpoint to the authenticity of the Qur'an. Syamsuddin Arif in his oriental book and diabolism of thought as quoted above.

As a Muslim should know that the Qur'an is the only holy book that declares itself clean from doubt and there is no human intervention in it, therefore it can be ascertained that the Qur'an that existed at the time of the Prophet Muhammad until now can be ascertained wholeness and truth empirically.

\section{Bibliography}

Agustiar. (2015, Juli-Desember). Orientalis dan Perananannya dalam Mempelajari Bahasa Arab. Jurnal Kependidikan Islam, 1(2), 261.

al-A'zzami, M. (2005). The History of Quranic Text From Revelation to Compilation. (A. M. Toha, Trans.) Jakarta: Gema Islami.

Amal, T. A. (2001). Rekosnstruksi Sejarah Al-Quran. Yogyakarta: FkBA.

Arif, S. (2008). Orientalis dan Diabolisme Pemikiran. Jakarta: Gema Insani.

Armas, A. (2003). Pengaruh Kristen-Orientalis terhadap Islam Liberal: Dialog Interaktif dengan Aktifis Jaringan Islam Liberal. Jakarta: Gema Insani.

Assamurai, Q. (1996). Bukti-bukti Kebohongon Orientalis. Jakarta: Gema Insani Press.

Athaillah, A. (2007). Sejarah Alquran Verifikasi Tentang Otentisitas Alquran. Banjarmasin: Antasari Press. 
Goldziher, I. ( 1971). Muslim Studies. London.

Goldziher, I. (1991). Introduction to Islamic Theology and Law. (H. Setiawan, Trans.) Jakarta: INIS.

Goldziher, I. (2006). Madzahib al-Tafsir al-Islamiy. (M. A. Salamullah, Trans.) Yogyakarta: Elsaq Press.

Hanafi, A. (1981). Orientalisme Ditinjau Menurut Kacamata Agama (Quran dan Hadis. Jakarta: Pustaka al Husna.

Hasbiyallah, M. (2018, Desember 17). Pandangan Orientalis Terhadap Alquran. Diambil kembali dari https://tnnujabar.or.id/: https://tnnujabar.or.id/pandangan-orientalis-terhadap-al-quran/

Jamal, A. M. (1991). Membuka Tabir Upaya Orientalis dalam Memalsukan Islam. Bandung: Diponegoro.

Nurhaedi, D. (2003). Perkembangan studi di Kalangan Orientalis. Essensia, 4(2), 176.

Rahim, A. (2010, Desember). Sejarah Perkembangan Orientalisme. Jurnal Hunafa, 2(2), 184.

Said, E. W. ( 1996). Orientalism. (A. Hikmat, Trans.) Bandung: Pustaka.

Shihab, A. (1999). Islam Inklusif Menuju Sikap Terbuka Dalam Beragama. Bandung: Mizan.

Yurnalis, S. a. (2019, juni). Studi Orientalis Terhadap Islam, Dorongan dan Tujuan. Jurnal al-Aqidah, 11(1), 65.

Zuhdi, A. (2004). Pandangan Orientalis Barat Tentang Islam: Antara yang menghujat dan Memuji. Surabaya: Karya Pembina Swajaya. 